\title{
Comparative Analysis of Several Global Terrorist Attacks in 2016
}

\author{
Zhibo Nie ${ }^{1,2^{*}}$, Minle Wang1, Youming Jia ${ }^{1}$, Huining Sun ${ }^{2}$ \\ ${ }^{1}$ Xi' an HiTech Research Institute, Xi'an, China \\ ${ }^{2} \mathrm{Xi}$ 'an University of Engineering, Xi'an, China \\ Email: *nerpenmath@yeah.net
}

How to cite this paper: Nie, Z.B., Wang, M.L., Jia, Y.M. and Sun, H.N. (2018) Comparative Analysis of Several Global Terrorist Attacks in 2016. Open Journal of Social Sciences, 6, 349-357. https://doi.org/10.4236/jss.2018.612030

Received: December 15, 2018 Accepted: December 28, 2018 Published: December 31, 2018

Copyright (C) 2018 by authors and Scientific Research Publishing Inc. This work is licensed under the Creative Commons Attribution International License (CC BY 4.0).

http://creativecommons.org/licenses/by/4.0/

\begin{abstract}
2016 has become history, but some terrorist attacks in 2016 still have guiding significance for the current anti-terrorism struggle. This paper makes a comparative analysis of several terrorist attacks in 2016 and points out that although the factors behind these attacks are different, terrorism, religious extremism and U.S. factors still dominate behind the events. Based on this analysis, some suggestions are put forward to safeguard national security and social stability.
\end{abstract}

\section{Keywords}

2016, Middle East, Europe, Terrorist Attacks, Comparative Analysis

\section{Introduction}

Since 2016, international terrorism has been on the rise. Frequent terrorist incidents are a major security issue for all countries and the international community. According to incomplete statistics of Global Terrorism Database (GTD), there were 104 major terrorist attacks in the world in the first 3 days of January of 2016.

With the shift of U.S. strategic focus and the imbalance of Gulf security pattern, terrorist organizations in the Gulf have revived, Al-Qaeda in the Arab region has not been eliminated, and terrorist organization "Islamic State" (IS) has launched attacks in Iraq and Syria, and its influence has expanded to Saudi Arabia, Kuwait, Egypt, Tunisia, France and the United States. Terrorist attacks in Gulf region occur almost every day, and the Gulf has become the source of terrorism in neighboring countries and regions. Terrorist organizations and attacks in Yemen, Syria, Egypt, Libya, Kenya, Djibouti, Somalia and other countries can all find their source in the Gulf [1].

In Europe, by August of 2016, there were nine major terrorist attacks in Turkey and several terrorist attacks in France and Belgium (data sources, according 
to xinhua.com). Due to the frequent terrorist attacks, the British Foreign Affairs and Association of Nations Office even released a map of the risk of terrorist attacks in 2016. In a survey conducted in Germany, 73\% of respondents expressed concern about terrorism due to repeated terrorist attacks [2]. These terrorist attacks clearly show that the "wave of religious extremism" with obvious Muslim ethnic characteristics, Islamic extremism and terrorist religious characteristics has swept across Europe, and contemporary Europe has become a major disaster area for international terrorism [3].

At the same time that terrorism swept Europe, "a new version of ' $C$ ' terrorism map" [4] from Southeast Asia through South Asia and the Middle East to Africa has been formed in the world. Since 2016, many terrorist attacks have taken place in Southeast Asian countries. Three major terrorist organizations in Africa, Boko Haram, Al-Shabaab in Somalia (both of which have been recruited by Islamic State (IS)) and the North Africa branch of Al-Qaeda, have taken hostages, massacred and committed many terrorist attacks in Africa. The United States was also not spared. The gay bar shooting that killed 49 people in June was considered to be the worst local terrorist attack since "9.11" and three consecutive terrorist attacks happened since September.

Studying the global terrorist events in 2016 is of practical significance to improving our anti-terrorism ability and thinking and maintaining the country's long-term stability.

\section{The Main Body Division of Terrorist Attackers}

In 2016, violent terrorism gradually swept across the world, and the main attackers of terrorist attacks in Asia, Africa, Europe and the United States have distinct characteristics.

\subsection{Terrorist Attacks by Global Terrorist Organizations Such as "Islamic State" and Al-Qaeda}

At present, "Islamic State" has become a common terrorist threat to the international community. As the main terrorist attackers in the Middle East and North Africa in 2016, its international influence continues to increase and it has become the actual leader of the international "jehad" under the impetus of a series of terrorist attacks and propaganda strategies.

Since 2016, "Islamic State" has caused a large number of terrorist attacks in Syria, Iraq, Saudi Arabia, Turkey and other countries. Other local terrorist organizations that have recruited and pledged allegiance to it have also launched several terrorist attacks in corresponding regions. Al-Qaeda has also carried out several terrorist attacks in South Asia and West Africa.

\subsection{Terrorist Attacks by Regional Terrorist Organizations, Religious Extremist Organizations and Opposition Armed Organizations}

In 2016, a number of religious extremists and terrorist organizations active on 
the line from Southeast Asia to the Gulf also caused a large number of terrorist attacks. On January $2^{\text {nd }}$, an extremist organization attacked an Indian air force base. Within Pakistan, Taliban launched several attacks. Bangladesh's domestic extremist forces launched a terrorist attack on foreigners in the capital Dhaka on the night of July $1^{\text {st }}$. PKK militants claimed to have caused several explosions in Turkey, including a car bomb attack on the police in Elazig province in eastern Turkey on September 18.

\section{3. "Lone Wolf" Terrorist Attack by Radical Individual}

On March, 22, 2016, Islamic extremists committed a series of bombings in Brussels, the capital of Belgian. French President Hollande said there is no denying the "terrorist nature" of the collision shooting incident that killed many people in Nice on the night of July $14^{\text {th }}$. On June $12^{\text {th }}$, a local extremist committed a mass shooting at a bar in Orlando, Florida, followed by three consecutive terrorist attacks in the United States in September.

\section{Analysis of Independent and Comprehensive Factors of Terrorist Attacks}

In 2016, the violence and terror in Asia, Africa, Europe and the United States appeared to have their own independent factors and characteristics. At the same time, there are still many common factors behind them, which makes some seemingly accidental incidents inevitable.

\subsection{Analysis of Independent Factors of Terrorist Attacks}

\subsection{1. "Islamic State" and "Al Qaeda" Factors of Terrorist Attacks}

Most of the terrorist attacks in Europe, Africa and South Asia in 2016 have the shadow of "Islamic State" or Al-Qaeda. The strategy of "Islamic State" to advocate the rapid establishment of power in its controlled areas and the implementation of strict Islamic Shariah rule is more attractive and practical than the strategy of "Al Qaeda" to strike the West first, then strike its allies and finally establish a "caliphate" empire. Therefore, "Islamic State" has rapidly emerged as a new standard bearer of global terrorism, and the new route of "nation-building" represented by it has been followed by more terrorist forces [4]. Against this background, many terrorist organizations under the leadership of "Islamic State" launched several terrorist attacks in Asia, Europe and Africa.

\subsubsection{The Racist Background and Extremist Factors of the Subject of Terrorist Attacks}

The terrorist attacks in France and Belgium [5] were both initiated by local second-generation Muslims, who had gone through the psychological process of returning to Islam to find their spiritual home and straying into religious extremism and "Islamic State" propaganda trap before launching the terrorist attacks, and carried out local "jehad" in Europe under the guidance of extremist religious forces under the banner of Islam. The terrorist attack in Bangladesh 
was also a direct attack on Christians by local religious extremists. The terrorist attackers in the United States have also been the second generation Muslims and have gone through a psychological process of "self-extremism", thus launching many terrorist attacks in the United States.

It should be noted that Europe also has the historical background of extremism of far-right wing forces such as local racism. In recent years, far-right wing forces have risen in Europe and made some terrorist attacks [6]. In the future, terrorist attacks from far-right wing forces will also increase.

\subsubsection{The Comprehensive Influence of Various Factors}

In 2016, the Indian air force terrorist attack by Al-Qaeda in January had obvious geopolitical and historical legacy factors, with India accusing Pakistan of covering up terrorist attacks. A series of terrorist attacks in Africa are influenced by religious extremism, terrorism, government corruption, the continuing economic downturn and various local and foreign forces. In a series of attacks in Turkey, there are not only "Islamic State" retaliation, political demands of various religious extremist forces, but also the factors of the decline of security capability caused by Kurdish Workers' Party armed retaliation and domestic political instability, as well as the factors of unfavorable international cooperation such as the hangover from the shooting down of Russian aircraft and the game between the relevant big powers for various interests. There are many headquarters or offices of extremist or terrorist organizations in Turkey, as well as unfavorable geographical factors and refugee influences in the immediate vicinity of war zones and the buffer zone leading to Europe, all of which lead to frequent terrorist incidents in Turkey.

\subsection{Analysis of Comprehensive Factors of Terrorist Attacks}

\subsubsection{Religious Sectarian Conflict and Religious Political Conflict}

"Islamic" countries practice the Islamic sharia of combining religion with politics, that is, religion and politics are inseparable. The struggle between Sunni and Shiite religious sects in the Islamic world is an important factor leading to unrest in the Middle East, followed by the emergence of "Islamic State", due to its "founding" concept and the comprehensive conflict with these two sects, resulting in chaos in the region. However, in line with the principle that the enemy of the enemy is a friend, as a Sunni "Islamic State", it is still supported by some Sunni countries in the Middle East to deal with Shiite-ruled Syria and other countries. Therefore, there are "Islamic State" almost everywhere in the Middle East. During this process, although the "Islamic State" took the opportunity to strengthen its strength, the reason behind the terrorist attacks in the Middle East and North Africa is still the religious struggle and religious political conflicts.

It can be predicted that the conflicts between "Islamic State" advocating the establishment of a purely religious state and the Sunni secular States that (once) supported it will also continue to accumulate. If "Islamic State" continues to be strong, these countries will face more security problems. 


\subsubsection{The Clash of Civilizations and the Failure of the Integration of Diverse Civilizations}

Huntington's analysis of the clash of civilizations is still applicable to summarizing the basic features of contemporary European terrorism and has certain practical significance for contemporary USA.

The real society and the relationship system are full of hegemonic, unequal and undemocratic contents. In a country with cultural diversity, the goal of multiculturalism is to demand the right to survival and development for the disadvantaged culture. For a strong culture, multiculturalism is not only an opportunity to express self-confidence, but also a smokescreen to conceal the essence of its hegemony and prevent others from getting involved in its special interests [7].

In contemporary Europe, the number and proportion of the second and the third generation of immigrants of Muslims have gradually increased with the decline of the fertility rate of white Europeans, but Muslim groups are still not the mainstream social groups in many aspects, such as social situation and economic income, so the loss and dissatisfaction of Muslim groups are gradually increasing. At the same time, Islamic extremist thought developed rapidly and affected the whole world. Therefore, some lost Muslims in Europe accepted extremist thought [8] in the process of returning to Islam to seek spiritual sustenance, and extremist organizations such as "Islamic State" took advantage of European Muslim descendants and introduced it step by step into the camp of violent terrorism. At present, the proportion of jehadists in Belgium is the highest in Europe, while the absolute number of them in France is the highest [9]. The core region of Europe has become a hotbed of terrorism and extremist forces.

Similar to Europe, the United States, far away from the terrorist type $\mathrm{C}$ zone, also faces the same serious fact: almost every terrorist attack in the United States after 911 was launched by local terrorists, the Boston marathon bombing, Orlando gay bar shooting and San Bernardino shooting etc.

\section{3. "More Fight, More Terrorism" Caused by Big Country Game}

In 2016, in the analysis of the factors that caused the global terrorist attacks, the big power game is still an important reason. The general international community believes that poverty, the gap between the rich and the poor, injustice, undemocratic and ethnic and religious conflicts are the basic elements of terrorism. Once these basic elements are in place, terrorism may occur under the influence of the environment. On the contrary, some western powers believe that "corrupt", "undemocratic" or "failed" countries are the root causes of terrorism, and their overall foreign policy is to solve the problems of these "undemocratic" countries, "corrupt" countries and "failed" countries. Therefore, through the big power game, the original balance of power in countries such as Afghanistan, Iraq and other countries that have been directly hit by a western big power in history and in Egypt, Libya, Syria and other countries that have undergone democratic transformation has been broken, the ruling government has been overthrown or 
the control ability has dropped sharply, terrorist organizations and extremist forces have risen and attacks have occurred frequently. Under the influence of this big country, the top 10 countries (with high incidence of terrorist attacks) of origin of (war) refugees who fled to Europe from 2008 to 2015 are almost all countries that have been hit by their wars (such as Iraq, Afghanistan, etc.) or have been hit by their enemies regularly in other countries (such as Pakistan, etc.) or have been or are undergoing civilization transformation (Syria, etc.), while the rest are almost all countries threatened by their clamor, such as Iran and Russia [10]. The Iraq war launched by the United States has the direct relationship with Islamic State which has directly affected the global security situation. Therefore, the more the United States intervenes, the more extremist terrorist organizations there will be. So many U.S. officials now say that it is only a matter of time before the U.S. may suffer another major terrorist attack [11].

\section{Enlightenment to China's Social Stability}

At present, Chinese society is in a critical period of reform and opening up, with social stability and the ruling party having a strong ability to repair itself. However, the complicated and changeable international environment and economic downturn, unbalanced regional development, widening gap between the rich and the poor and some problems left over from history, especially some violent and terrorist incidents in border areas such as 3.01 in Kunming city, Yunnan province and 5.22 in Urumqi explosive terrorist Case in recent years, have to some extent affected social stability.

Through the analysis of the terrorist attacks abroad in 2016, it can provide some ideas for China's security and stability.

\subsection{Firmly Prevent the Ideological Field from Becoming Extremist}

1) According to foreign experience, violent terrorists all have a process of ideological extremism before they can be implemented as violent terrorist incidents. Therefore, China must resolutely eliminate the process of extremism, resolutely crack down on the three forces, and prevent the spread of extremist ideas and terrorist forces from abroad to the frontier and the mainland.

2) To prevent interference from foreign forces, especially the peaceful evolution of foreign anti-China forces in the ideological field and the negative influence of foreign bad culture on the next generation and young people, and to keep a clear head.

\subsection{Actively Promote Reform and Improve the Ruling Ability}

1) One of the sources for the development of violent terrorism is the area where the government's governing capacity is degraded. Therefore, to prevent violent terrorism from spreading to the country, it is crucial to enhance the government's governing capacity. 
2) A strong military force is the basis for combating terrorism and maintaining social stability. We should strengthen the building of anti-terrorist forces and other security forces and mechanisms and maintain a strong ability to combat and deter violent terrorism.

3) International cooperation is a basic strategy to combat and prevent foreign terrorist forces from infiltrating into China, an important means to prevent extremist ideological trends, and an effective way to prevent terrorist incidents from being planned abroad and implemented inside China. It is necessary to combat terrorism at its root by strengthening international anti-terrorism cooperation.

\section{Enlightenment to Anti-Terrorism Struggle}

On the basis of strengthening conventional preparations for the fight against terrorism, such as border control, war law drills, intelligence and information acquisition capabilities, and command system construction, the anti-terrorist forces should focus on the need for "going out strategy" and also pay attention to the following points.

\subsection{Increase the Research and Exercise of Counter-Terrorism against Innovative Means of Terrorism}

At present, the terrorist attacks in China are mainly launched by the "three forces" and are restricted by such conditions as geography, economic strength, scientific and technological level, and personnel characteristics. The characteristics of the terrorist attacks launched by the "three forces" are obvious. Therefore, the domestic main anti-terrorism forces are also mature in their means of preventing the "three forces" from carrying out terrorist attacks. However, with the continuous innovation and development of terrorist attacks by foreign terrorist forces, the "three forces" of internal and external collusion have also evolved in their ways of launching terrorist attacks. Therefore, more research and response exercises should be conducted on innovative terrorist acts at home and abroad.

\subsection{Strengthen the Research and Practice of Daily Service Innovation Such as Domestic and Overseas Security Guards, Duty Guards and Emergency Guards}

The anti-terrorist forces have accumulated a great deal of experience in security guard, guard, duty and emergency terrorism. However, with the constant innovation of domestic and foreign terrorist attack implementation and security measures, the anti-terrorist forces should also strengthen the innovation research of daily service. From the terrorist attacks in Nice of France and New York of the USA in 2016, terrorists all broke through the security forces' defense in advance or in real time and then carried out terrorist attacks. Therefore, on the basis of existing experience, the innovation research on conventional security guard, duty and emergency security should be increased, especially on large gatherings and holidays. 


\subsection{Strengthen the Construction, Innovation and Exercise of New Special Forces}

The special forces play an irreplaceable role in the fight against terrorism. Whether there is an appropriate special force to fight will directly affect the effectiveness of the fight against terrorism. Therefore, the special forces should focus on the "going out strategy" needs, strengthen the construction of special forces capabilities with future overseas combat capabilities, strengthen the innovation of warfare methods and actual combat practice, adapt to the overseas combat needs under the future high-tech conditions, adapt to the anti-terrorism needs of desert, alpine mountain, jungle, sea and other harsh environment areas, and lay a solid foundation for maintaining national stability and protecting overseas interests.

To sum up, violent terrorism is a cancer of national stability and development. Although the study of terrorist attacks in 2016 is incomplete in sampling, but analyzing the development trend of international terrorism in 2016 made us clearly understand when and where terrorist incidents occur, which groups of people tend to become terrorists, and the impact of the above factors on the anti-terrorist policies of various countries. We can fully recognize the development trend of international terrorism, predict the high incidence areas of terrorist incidents in the future, predict the types of terrorists, provide advice for national anti-terrorism strategies, improve the research level of anti-terrorism struggle, strengthen the pertinence of anti-terrorism military struggle, and ensure the long-term stability and security of our country.

\section{Conflicts of Interest}

The authors declare no conflicts of interest regarding the publication of this paper.

\section{References}

[1] Liu, J.M. (2015) Gulf Chaos, Obama Doctrine and US Adjustment of Gulf Policy. Contemporary World and Socialism, No. 6.

[2] Xinhua.com. (2016).

[3] Song, Q.C. (2014) Ethnic Secession and Religious Conflict: Terrorism in Contemporary European Countries. Contemporary World Socialism, No. 3.

[4] Yan, S. (2015) Characteristics and Development Trend of International Terrorism at Present. Modern International Relations, No. 1.

[5] Yang, S. (2016) A Serial Explosion in the Heart of Belgium. International Business News, March 2016, 24(A04).

[6] Song, Q.C. (2014) Ethnic Secession and Religious Conflict: Terrorism in Contemporary European Countries. Contemporary World Socialism, No. 3.

[7] Huang, L.Z. (2003) Paradox of Multiculturalism-Re-Evaluation of Huntington's Theory. Philosophy Research, No. 9.

[8] Kirk, A. (2016) Iraq and Syria: How Many Foreign Fighters, Fighting for Isil? https://www.telegraph.co.uk/news/2016/03/29/iraq-and-syria-how-many-foreign-fi 
ghters-are-fighting-for-I

[9] Hecker, M. (2015) “Jihad”: Challenges Faced by France. International, No. 2.

[10] Wang, L. (2016) Refugee Crisis and "Islamization" in Europe. Xue Ha, 4.

[11] Li, W. (2009) The US Root Cause of Anti-Vietnam Terror from Mumbai Attacks. World Economy and Politics, First Half of 2009. 